Association for Information Systems

AIS Electronic Library (AISeL)

ICEB 2002 Proceedings

International Conference on Electronic Business

(ICEB)

Winter 12-10-2002

\title{
A Multiple Criteria Decision Support Web-based System for Facilities Management
}

Edmundas Kazimieras Zavadskas

Arturas Kaklauskas

Antanas Zenonas Kaminskas

Andrius Gulbinas

Natalija Lepkova

See next page for additional authors

Follow this and additional works at: https://aisel.aisnet.org/iceb2002

This material is brought to you by the International Conference on Electronic Business (ICEB) at AIS Electronic Library (AISeL). It has been accepted for inclusion in ICEB 2002 Proceedings by an authorized administrator of AIS Electronic Library (AISeL). For more information, please contact elibrary@aisnet.org. 


\section{Authors}

Edmundas Kazimieras Zavadskas, Arturas Kaklauskas, Antanas Zenonas Kaminskas, Andrius Gulbinas, Natalija Lepkova, and Jurate Kaklauskiene 


\title{
A Multiple Criteria Decision Support Web-Based System for Facilities Management
}

\author{
Edmundas Kazimieras Zavadskas \\ Rector of Vilnius Gediminas \\ Technical University \\ Sauletekio al. 11, LT-2040 \\ Vilnius, Lithuania
}

\section{Andrius Gulbinas \\ Vilnius Gediminas Technical University}

Sauletekio al. 11, LT-2040 Vilnius, Lithuania

\author{
Arturas Kaklauskas \\ Chairman of Department of \\ Construction Economics and \\ Property Management \\ Vilnius Gediminas Technical \\ University \\ Sauletekio al. 11, LT-2040 \\ Vilnius, Lithuania \\ Arturas.Kaklauskas@st.vtu.lt
Natalija Lepkova
Vilnius Gediminas Technical University
Sauletekio al. 11, LT-2040
Vilnius, Lithuania

\author{
Antanas Zenonas Kaminskas \\ Chancellor of Lithuanian \\ Government \\ Gedimino pr. 11, \\ Vilnius, Lithuania \\ a.z.kaminskas@1rvk.lt
}

\author{
Jurate Kaklauskiene \\ Vilnius Gediminas Technical \\ University \\ Sauletekio al. 11, LT-2040 \\ Vilnius, Lithuania
}

\begin{abstract}
An analysis of multiple criteria decision support systems and facilities management Web-based automation applications that were developed by researchers from various countries assisted the authors to create one of their own Multiple Criteria Decision Support Web-Based System for Facilities Management (DSS-FM). DSS-FM differs from others in its use of new multiple criteria analysis methods as were developed by the authors. The database of a facilities management was developed and provides a comprehensive assessment of alternative versions from the economic, technical, technological, infrastructure, qualitative, technological, legislative and other perspectives. Based on the above complex databases, the developed Multiple Criteria Decision Support Web-Based System for Facilities Management enables the user to analyze alternatives quantitatively and conceptually. Applying the DSS-FM may increase the efficiency of calculators, analyzers, software, neural networks, expert and decision support systems and e-commerce.
\end{abstract}

One of the major problems in e-business is to find what you want. The number of alternative products and services on the Internet are in the thousands. How can customers find the rational products and services on the Internet? Once product or service information is found, the customer usually wants to compare alternatives.

The major players in facilities management Web sites can find calculators, analyzers, software, neural networks, expert and decision support systems and e-commerce, etc. According to B .K. Forbes [1] [2], the top seven facilities management automation application areas follows: real property and lease management, strategic master planning, space management, furniture and equipment management, telecommunications and cable management and building operations management.

A calculator is software application that is used for completing mathematical calculations. Facilities management Web sites sometimes contain calculators: CRESA Space Calculator [7] (calculates office space needs), Comfort calculator [8] (analyzes thermal comfort and estimates the optimal temperature), etc.

Web sites might also contain various purpose analyzers [9, etc.] that help customers to analyze various facilities management situations.

Information about facilities management software can be found on the following facilities management Web sites: ARCHIBUS/FM [10], FM Systems [11], etc. The above facilities management software offers various modules and tools: lease management, move management, strategic space planning, maintenance management, accounting charge-back, communication/cable management and personnel management.

Expert systems [12, etc.] today generally serve to relieve a 'human' professional of some of the difficult but clearly formulated tasks.

The major players in facilities management can use various purpose decision support systems [13, etc.]. The decision support system (DSS) provides a framework through which decision-makers can obtain the necessary assistance for decisions through an easy-to-use menu or command system.

The above calculators, analyzers, software, neural networks, decision support and expert systems, ecommerce, etc, are not connected. Therefore, in the future the above FM automation solutions to some extent must be integrated.

Based on the analysis of the multiple criteria decision support systems and facilities management Web-based automation applications and in order to determine the most efficient versions of real estate and facilities 
management, a Multiple Criteria Real Estate ECommerce System was developed. The Multiple Criteria Decision Support Web-Based System for Facilities Management (DSS-FM) consisting of a database, database management system, model-base, model-base management system and user interface is a part of the Multiple Criteria Real Estate E-Commerce system and was developed by the authors of this research. A short description of the DSS-FM follows.

Facilities management involves a number of interested parties who pursue various goals and have different potentialities, educational levels and experiences. This leads to various approaches of the above parties to decision-making in this field. In order to do a full analysis of the available alternatives and to obtain an efficient compromise solution, it is often necessary to analyse economic, qualitative, legal, social, technical, technological, space and other type of information. This information should be provided in a user-oriented way.

The presentation of information needed for decisionmaking in the DSS-FM may be in a conceptual form (i.e. digital/numerical, textual, graphical, diagrams, graphs and drawing, etc), photographic, sound, video and quantitative forms.

The presentation of quantitative information involves criteria systems and subsystems, units of measurement, values and initial weights that fully define the provided variants. Conceptual information means a conceptual description of the alternative solutions, the criteria and ways of determining their values and the weights, etc.

In this way, the DSS-FM enables the decision-maker to receive various conceptual and quantitative information on facilities management from a database and a modelbase allowing him/her to analyse the above factors and to form an efficient solution.

The analysis of database structures in decision support systems according to the type of problem solved reveals their various utilities. There are three basic types of database structures: hierarchical, network and relational. DSS-FM has a relational database structure where the information is stored in the form of tables. These tables contain quantitative and conceptual information. Each table is given a name and is saved in the computer's external memory as a separate file. Logically linked parts of the table form a relational model.

To design the structure of a database and perform its completion, storage, editing, navigation, searching and browsing etc. a database management system was used in this research.

The user seeking for an efficient facilities management solution should provide, in the tables assessing facilities management solutions, the exact information about alternatives under consideration as to the client's financial situation. It should be noted that various users making a multiple criteria analysis of the same alternatives often get diverse results. This may be due to the diversity of the overall aims and financial positions of the users. Therefore, the initial data provided by various users for calculating the facilities management project differ and consequently lead to various final results.
The character of the objective's choice for the most efficient variant is largely dependent on all available information. It should also be noted that the quantitative information is objective. The actual facilities management services have real costs. The values of the qualitative criteria are usually rather subjective though the application of an expert's methods contributes to their objectivity.

The interested parties have their specific needs and financial situation. Therefore, every time when the party uses the DSS-FM they may make corrections to the database according to their aims and their financial situation.

The efficiency of a facilities management variant is often determined by taking into account many factors. These factors include an account of the economic, aesthetic, technical, technological, management, space, comfort, legal, social and other factors. The model-base of a decision support system should include models that enable a decision-maker to do a comprehensive analysis of the available variants and to make a proper choice. The following models of a model-base aim at performing the functions of: a model for the establishment of the criteria weights; a model for multiple criteria analysis and for setting the priorities; a model for the determination of a project's utility degree; a model for the determination of a project's market value.

According to the user's needs, various models may be provided by a model management system. When a certain model (i.e. search for facilities management alternatives) is used the results obtained become the initial data for some other models (i.e. a model for multiple criteria analysis and setting the priorities). The results of the latter, in turn, may be taken as the initial data for some other models.

The management system of the model base allows a person to modify the available models, eliminate those that are no longer needed and add some new models that are linked to the existing ones.

The following multiple criteria analysis methods and models as developed by the authors (Kaklauskas, A., Zavadskas E. [3] [4] [5] [6] are used by the DSS-FM in the analysis of the facilities management alternatives: a new method and model of complex determination of the weight of the criteria taking into account their quantitative and qualitative characteristics was developed; a new method and model of multiple criteria complex proportional evaluation of projects enabling the user to obtain a reduced criterion determining the complex (overall) efficiency of the project was suggested.

In order to find what price will make a valuated project competitive on the market a method and model for determining the utility degree and market value of projects based on the complex analysis of all their benefits and drawbacks was suggested; a new method and model of multiple criteria multi-variant design of a project's life cycle enabling the user to make computeraided design of up to 100,000 alternative project versions was developed. Any project's life cycle variant obtained 
in this way is based on quantitative and conceptual information.

Application of Multiple Criteria Decision Support Web-Based System for Facilities Management (DSS-FM) allows one to determine the strengths and weaknesses of each phase and its constituent parts. Calculations were made to find out by what degree one version is better than another and the reasons disclosed why it is namely so. Landmarks are set for an increase in the efficiency of facilities management versions. All this was done argumentatively, basing oneself on criteria under investigation and on their values and weights. This saved users' time considerably by allowing them to increase both the efficiency and quality of facilities management analysis.

Below is a list of typical facilities management problems that were solved by users: multiple criteria analysis of space management, administrative management, technical management and management of other services alternatives; analysis of complex facilities management alternatives; analysis of interested parties (competitors, suppliers, contractors, etc.); determination of efficient loans; analysis and selection of rational refurbishment versions (e.g. roof, walls, windows, etc.); multiple criteria analysis and determination of the market value of a real estate (e.g. residential houses, commercial, office, warehousing, manufacturing and agricultural buildings, etc.); analysis and selection of a rational market; determination of efficient investment versions, etc.

\section{Conclusions}

Facilities management is an information business. Technological innovation mainly through changes in the availability of information and communication technology inclusive calculators, analysers, software, neural networks, decision support and expert systems, ecommerce that have been provided by a variety of new services developed by the facilities management sector. Most of all calculators, analysers, software, decision support and expert systems, neural networks seek to find out how to make the most economic facilities management decisions and most of all these decisions are intended only for economic objectives. Facilities management alternatives under evaluation have to be evaluated not only from the cost (design, construction, indirect expenses, operating and maintenance expenses, renovation costs, the interest paid on loan), but take into consideration qualitative, technical, technological, space and other characteristics as well. Therefore, applying multiple criteria analysis methods and decision support systems may increase the efficiency of facilities management calculators, analysers, software, neural networks, decision support and expert systems, ecommerce. Based on an analysis of multiple criteria decision support systems and facilities management Web- based automation applications and in order to determine the most efficient versions of facilities management Multiple Criteria Decision Support Web-Based System for Facilities Management was developed by authors of paper. The related questions were analysed in this paper.

\section{References}

[1] B.K.Forbes, A.R.Forbes, J.M.Forbes, C.M.Zawadski (20001). Facilities Management Automation and Infrastructure Management. Facilities Engineering and management Handbook. Commercial, Industrial, and Institutional Buildings. McGraw-Hill.

[2] B.K.Forbes, J.M.Forbes, R.E.Forbes, C.M.Zawadski (20001). The Role of E-Commerce and Business-to-Business Electronic Marketplaces in Facilities Management. Facilities Engineering and management Handbook. Commercial, Industrial, and Institutional Buildings. McGraw-Hill.

[3] Kaklauskas, A. (1999) Multiple criteria decision support of building life cycle. Research report presented for habilitation. Technological sciences, civil engineering (02T), Vilnius Gediminas Technical University, Technika.

[4] Kaklauskas, A., Lepkova, N. (2001), Facilities management object and miltiple criteria analysis // Modern building materials, structures and techniques: abstracts of 7 th international conference, held on May 16-18, 2001 Vilnius, Lithuania / VGTU. - Vilnius : Technika, p.170-171.

[5] Kaklauskas A., Zavadskas E. K., Gikys M., Gulbinas A. (2001), Efficiency increase of property e-business systems by applying multiple criteria decision support systems // 54emes Journées du Groupe de Travail Européen : "Aidemulticritere a la décision", 4 et 5 octobre 2001- Durbuy: "Multicriteria aid for decisions", Durbuy- October 4 and 5, 2001 : programme.p.1-9.

[6] A. Kaklauskas, E.K.Zavadskas, P.Vainiunas (2001). Efficiency Increase of Real Estate E-Business Systems by Applying Multiple Criteria Decision Support Systems. Proceedings. Eighth European Real Estate Society Conference, Alicante, June 26-29.

[7] "Industry resources- CRESA Space Calculator",

Available http://www.naiop.org/resources/assets.shtml (Accessed: 2002, January).

[8] "My facilities.com-comfort calculator", Available: http://www.automationcollege.com/myfacilities/tools/comfortca lculator.asp (Accessed: 2002, January)

[99] "QPS, Inc - property analyzer", Available :http://www.qualityplans.com/propertyanalyser.htm (Accessed: 2002, January)

[10] "Archibus, Inc-ARCHIBUS/FM software", Available: http://www.archibus.com/ (Accessed: 2001,October)

[11] "FM: Systems, Inc"-FM:Interact and FM:Space software, Available: http://www.fmsystems.com, (Accessed: 2002, January)

[12] "NECA" -Safety Expert Software, Available: http://www.vulcanpub.com/ecen/article.asp?article_id=59995 (Accessed: 2002, January)

[13] "PCSWMM 2000-decision support system", Available: http://www.chi.on.ca/pcswmmdetails.html (Accessed: 2002, February) 